UDK 347.91

DOI: $10.5937 / \mathrm{RKSPP} 2102135 \mathrm{~L}$

MILAN LAZIĆ

MILICA SAVIĆ

\title{
THIRD PARTY FUNDING AND ACCESS TO JUSTICE
}

The purpose of this paper to analyze whether and to what extent are third-party funding and access to justice intertwined and compatible. The analysis started from recognizing most common challenges with third-party funding and whether these challenges may be overcome with existing regulation and guidelines. Global lack of regulation of this subject is noticeable. This increases the risks of having undisclosed conflict of interests between various participants and affects the confidentiality, efficiency and fairness of the proceedings and ultimately the access to justice considerations. Although third party funding undoubtedly contributes to larger access to justice, an unregulated market of this kind may also draw adverse inference to the access to justice. In conclusion, authors of this paper call for wider regulation of this matter, including both through local legislation and arbitration rules.

Key words: arbitration, third-party funding, conflict of interest, access to justice, confidentiality

\section{N T R O D U C T I O N}

The notion of third-party funding has become quite regular in international arbitration and dispute resolution in general. In fact, it is old news in western jurisdictions, especially in the United Kingdom and the United States. In more recent

Milan Lazić, Senior Partner at Karanović \& Partners law office, Belgrade, attorney at law, e-mail:milan.lazic@karanovicpartners.com.

Milica Savić, Partner at Karanović \& Partners law office, Belgrade, attorney at law, e-mail: milica.savic@karanovicpartners.com. 
years, it has also become a standard in the western Balkan region, with numerous disputes being financed by third-party funders. This is especially the case with investment arbitrations against the states in this region, as these disputes are of appropriate magnitude and value to stir the interest amongst the financiers. Commercial disputes, either arbitrations or disputes before local courts in this region, have not been attractive for third-party funders, as they are not of the value profitable enough for the funders who also do not have sufficient reliability in the court system and generally in the rule of law in the countries of western Balkan.

If someone had said three decades ago that third parties will offer their funds to finance the disputes that have absolutely nothing to do with them and that this is going to be a profitable business, we might have even said that something like that is unallowed and unethical. Historically, common law jurisdictions institutes of "maintenance" and "champerty" were designed to prevent third parties from profiting in the litigation in which they are outsiders for the concern of the rise in frivolous or vexatious litigation. ${ }^{1}$ The debate whether third-party funding can be leveled with "maintenance" and "champerty" is ongoing. ${ }^{2}$ However, precisely for the reasons of improving access to justice the common law countries have departed from the institutes of "maintenance" and "champerty" and adopted a more flexible and friendly attitude towards third-party funding. ${ }^{3}$

Third-party funding has come a long way from being considered almost illegal or unethical to being the usual practice which is even regulated in some countries and by certain arbitration rules. Third-party funding became an important tool for access to justice to parties that do not have sufficient funds to finance the expensive tribunals and court proceedings.

What we are wondering in this paper is how we came about from the perspective that third party funding is unethical to the point of third-party funding being a regulated usual practice and what has changed in the perspective. We also wonder whether third-party funding positively contributed to access to justice, and whether third-party funders make positive or negative differentiation between certain types of claims and potential claimants. In this paper, we analyze how not to

1 Third Party Funding in International Arbitration, https://www.ashurst.com/en/news-andinsights/legal-updates/quickguide---third-party-funding-in-international-arbitration/, accessed 23 September 2021.

2 Hong-Lin Yu, "Can Third Party Funding Deliver Justice in International Commercial Arbitration?", International Arbitration Law Review, 2017, 20-34.

3 Third Party Funding in International Arbitration, https://www.ashurst.com/en/newsand-insights/legal-updates/quickguide---third-party-funding-in-international-arbitration/, accessed 23 September 2021. 
spoil the positive trend of third-party funding and its contribution to the access to justice ideal by analyzing different challenges with third-party funding (section 2). Thereafter, we analyze how lawyers and advisors treat the cases potentially funded by third parties and how they handle potentially conflicting instructions from the funder and the client (section 3). We then assess the benefits of third-party funding and assess whether it positively contributes to the notion of access to justice and what needs to be done to maintain its positive contribution (section 4). Finally, we conclude with some recommendations and general remarks on how the practice of third-party funding coincides with access to justice needs and look for ways to further improve this connection (section 5).

\section{SOME CHALLENGES WITH THIRD-PARTY FUNDING}

\section{General}

Although a common fixture within the arbitration community in recent years, third-party funding is still inconsistently (not) regulated by different institutions' arbitration rules and incoherently observed by arbitral tribunals with much diversity in standards, making it one of the most debated issues in international arbitration.

ICC Arbitration Rules ${ }^{4}$ and VIAC Rules ${ }^{5}$ introduced a requirement of party disclosure of third-party funding arrangements, starting from 1 January 2021 and 1 July 2021, respectively. On the other hand, although amended as recently as in 2020, LCIA Rules ${ }^{6}$ still do not recognize the need to formally regulate the issue of third-party funding, nor do UNCITRAL and ICSID Rules (although the 4th Edition of the ICSID Working Paper from February 2020 provided for an amendment to the ICSID Rules of Procedure for the incorporation of mandatory disclosure in cases of third-party funding arrangements, mandating a written notice by the funded party ${ }^{7}$ ).

Certain Asian jurisdictions have recognized the need to regulate third-party funding disclosure, either through arbitration rules or local legislation. CIETAC introduced this requirement already in 2017 in its investment arbitration rules ${ }^{8}$

4 ICC Arbitration Rules (2021), Article 11(7).

5 VIAC Rules of Arbitration and Mediation (2021), Article 13a.

6 LCIA (London Court of International Arbitration) Arbitration Rules (2020).

7 ICSID Working Paper, $4^{\text {th }}$ edition, February 2020.

8 CIETAC Investment Arbitration Rules, Article 27(2) (English Translation). 
and the CIETAC's Hong Kong Arbitration center issued Guidelines for Third-Party Funding in International Arbitration in 2016 also suggesting that parties obtaining funding should inform the tribunal of it without delay. ${ }^{9}$ In Singapore, an all-round regulation of third-party funding has been introduced by amendments to the Civil Law Act and Legal Profession Act as well as by enacting the Civil Law (Third Party Funding) Regulations 2017. In a nutshell, these regulations work three ways: (i) by providing that the funding contracts are not contrary to the public policy or illegal and by abolishing the Common law torts of maintenance and champerty, (ii) by allowing lawyers to promote, advise on and draft contracts for third-party funding and to act in funded disputes and (iii) by regulating some qualifications and requirement a third-party funder needs to meet in order to operate in Singapore. Most importantly, the obligation of lawyers to make a disclosure of third-party funding (and the identity of funders) in the proceedings was established, at the date of commencement of the dispute or as soon as practicable after the third-party funder entered the dispute. Similar regulation was introduced in Hong Kong. ${ }^{10}$

In any event, lack of uniform regulation of the topic still leaves much to interpretation when it comes to disclosing the existence of the funding arrangement and the identity of the funder, and practice of recent years has shown that this lack of uniform regulation leads to various challenges, most notably conflict of interest of arbitrators and issues of confidentiality.

\section{Disclosure and Conflict of Interest}

One of the numerous issues raised by the involvement of third-party funders in international commercial arbitration is arbitrator conflict of interest due to nondisclosure of the involvement of the third-party funder. In 2014, the International Bar Association (IBA) issued the IBA Guidelines on Conflicts of Interest in International Arbitration. The Guidelines address the question of disclosure of third-party funding agreements in the context of arbitrators' impartiality and independence, levelling the role of funders in an arbitration to that of the parties, stating the funders have a "direct economic interest in the award." 11 Although the IBA Guidelines have been met with affirmation within the arbitration community,

9 China International Economic and Trade Arbitration Commission, Hong Kong Arbitration Center, 2016, "Guidelines for Third Party Funding in Arbitration", Article 2.9.

10 Andrew G. Moran QC, "Ethical issues arising in connection with third party funding of international commercial arbitration”, Bani Conference in Jakarta, Indonesia, 29 November 2018.

11 IBA Guidelines on Conflicts of Interest in International Arbitration, 2014, General Standard 7(a). 
their effectiveness is of limited extent as their nature is to serve only as recommendations to parties and arbitral tribunals and they "do not override any applicable national law or arbitral rules chosen by the parties". ${ }^{2}$

The 2015 Queen Mary School of International Arbitration Survey has shown that $76 \%$ of survey respondents agreed that disclosure of the existence of third-party funding arrangements should be mandatory and $63 \%$ believed that disclosure of the identity of the funders should be mandatory. ${ }^{13}$ Observing these results, and the informal popular opinion within the arbitration community, it can be said there is general consensus that it is recommendable to disclose the existence of funders and their identity. ${ }^{14}$ However, lack of uniform regulation of this topic still leaves open issues such as who is required to make such a disclosure and when. Parties are therefore entitled to decide when and how to make any such disclosure, be it on their own initiative or complying with an order from the tribunal. It is of course essential that such disclosure is made, whenever possible, prior to the tribunal being constituted, so that each prospective arbitrator is able to comply with its duty to disclose any circumstances concerning the arbitrator's impartiality or independence which may arise during the arbitration.

Latest amendments to the ICC Rules provide a broad requirement of a prompt disclosure. ${ }^{15}$ The VIAC Rules have a more elaborate wording, requiring the parties to inform the tribunal with the statement of claim or immediately upon concluding the third-party funding agreement. The VIAC Rules also underline an obligation of the Secretary General to inform any arbitrator nominated for appointment or already appointed of such disclosure for purposes of completing the arbitrator declaration. ${ }^{16}$

In absence of any regulated obligation to disclose third-party funding, there is still ambiguity in understanding who is supposed to determine what constitutes

12 IBA Guidelines on Conflicts of Interest in International Arbitration, 2014, Introduction, point 6 .

13 Queen Mary, University of London and White \& Case, "2015 International Arbitration Survey: Improvements and Innovations in International Arbitration" (2015).

14 This is also in line with the IBA Guidelines on Conflicts of Interest in International Arbitration, as General Standard 7(a), requires as follows: "A party shall inform an arbitrator, the Arbitral Tribunal, the other parties and the arbitration institution or other appointing authority (if any) of any relationship, direct or indirect, between the arbitrator and the party (or another company of the same group of companies, or an individual having a controlling influence on the party in the arbitration), or between the arbitrator and any person or entity with a direct economic interest in, or a duty to indemnify a party for, the award to be rendered in the arbitration."

15 ICC Arbitration Rules (2021), Article 11(2).

16 VIAC Rules of Arbitration and Mediation, Article 13a. 
any relationship, direct or indirect, between the arbitrator and any person or entity with a direct economic interest in, or a duty to indemnify a party for, the award to be rendered in the arbitration. There were some broad interpretations of the General Standard 7 of the IBA Guidelines on Conflict of Interest that it is the arbitrators who are obliged to determine and disclose particular facts that may give rise to a conflict of interest, implying their duty to investigate. Unfortunately, the issue with this interpretation is that arbitrators have limited resources to investigate, unless they order certain disclosures, and arbitrators may issue orders only after their appointment is confirmed. This yingyang of duty and authority prompted the stance that the prevailing interest to determine relevant information and when disclosure is appropriate lies with the party and its funder as they are the ones interested to ensure the enforceability of the award. ${ }^{17}$

This brief overview shows that conflict of interest, no matter when it surfaces in the proceedings, either before or after the tribunal is constituted, significantly hampers efficiency and the purpose of arbitration. These risks could be decreased significantly with detailed regulating of the need to disclose inclusion of funders in the arbitration proceedings.

\section{Privilege and Confidentiality}

Third-party funding discussions most commonly focus on the issues of disclosure, arbitrator bias, security for costs, and regulation (or lack thereof) - not much attention was devoted to the issues of privilege and confidentiality. These issues involve, among others, how to maintain the confidentiality of arbitral proceedings that are confidential in nature ${ }^{18}$ given that the funded party is expected to disclose the details of the proceedings to funders, whereas the opposing party is providing information and documents in confidence. Funders are not generally regarded as bound by professional ethical rules regarding treatment of confidential information and conflicts of interest rules in the same way lawyers are. ${ }^{19}$ Therefore, a concern was raised that there is no legislative or other type of professional ban on third-party funders to use information of one party in another funded matter for a different party.

17 Report of the ICCA (International Council for Commercial Arbitration) - Queen Mary task force on third-party funding in international arbitration, The ICCA Reports No. 4, April 2018, 111-112.

18 Chitransh Vijayvergia, "Balancing Disclosure and Confidentiality Obligations in ThirdParty Funding”, Arbitration \& Corporate Law Review, 2020.

19 Report of the ICCA (International Council for Commercial Arbitration) - Queen Mary task force on third-party funding in international arbitration, The ICCA Reports No. 4, April 2018, 117-118. 
Increasing number of funded cases has also increased an already high level of complexity and uncertainty in dealing with confidential information and documents in international arbitration. ${ }^{20}$ As a reminder, resolving these issues is still, at least according to the IBA Rules on Taking of Evidence in International Arbitration, very much within the discretion of tribunals. Even though there is undisputed relevance of these issues, international conventions, and most national arbitration laws and arbitral rules are silent about issues of privilege and confidentiality (and related questions of conflicts of interest). ${ }^{21}$

In any event, having a third-party funder involved in the process undoubtedly introduces a risk that confidential information shared in an arbitration is at risk of being further exposed. Adequate mechanisms to protect that from happening should be included in the funding arrangement, so that the funder is at least contractually bound to protect the confidentiality of arbitration and information received therein. This again raises the question of whether details of a funding arrangement are to be disclosed in the arbitration.

IBA Rules on Taking of Evidence leave a very broad authority for the tribunal to protect confidentiality, as Article 9(4) provides that tribunals may, where appropriate, make necessary arrangements to permit evidence to be presented or considered subject to suitable confidentiality protection..$^{22}$ Leaving such broad authorities to the tribunal should be avoided or at least softened by introducing mechanisms and rules on how information or documents perceived as confidential are to be included in the arbitration (for instance as redacted materials), but with a clear order from the tribunal on limiting the purposes for which such information may be used.

Same principles should also be applied to the confidential nature and confidential segments of the agreement between the funded party and its funder. Although there is general consensus that the existence of funding and the identity of a third-party funder is not subject to any legal privilege, ${ }^{23}$ it is still debatable whether this consensus spreads to the details of the funding arrangement and to what extent. The specific provisions of a funding agreement may be subject to confidentiality obligations between the parties to that agreement and therefore could

${ }^{20}$ Jonas Von Goeler, "Third-Party Funding in International Arbitration and its Impact on Procedure", Kluwer Law International, 2016, 166.

21 Gary Born, International Commercial Arbitration, 2nd edition, 2014, 2376.

22 IBA Rules on the Taking of Evidence in International Arbitration, 2020.

23 Report of the ICCA (International Council for Commercial Arbitration) - Queen Mary task force on third-party funding in international arbitration, The ICCA Reports No. 4, April 2018, 117-118. 
include information subject to legal privilege. Consequently, production of such information should only be ordered in exceptional circumstances.

Relevance of details in the funding arrangement is most visibly noticeable in security for costs applications. It is still questionable whether the mere existence of a security for costs application is sufficient for the tribunal to order disclosure of the entire funding arrangement, not just the identity of the funder. Historically, arbitral tribunals have been sceptical about making such orders, ${ }^{24}$ however, further regulation of third-party funding disclosure in general might also bring certain changes to how security for costs applications, or even award on allocation of costs, are perceived.

\section{IN-BETWEEN A CLIENT AND A FUNDER \\ - WHO IS RUNNING THE SHOW?}

One of the basic notions of lawyers' ethics is the obligation of a lawyer to put the interests of a client before their own interest, the interest of their colleagues, other participants in the proceedings and third parties. ${ }^{25}$ In a funded case, the funder has an obvious economic interest in the outcome of the dispute. The funder is a third party with a very powerful leverage - funds that enable the claimant to access justice. That is why a common practice of funders worldwide was established of not imposing control over the dispute but letting the client make important decisions about the fate of the dispute - e.g. whether or not the case will be settled and for which amount. In any event, funding agreement will usually contain provisions that deal with settlement and, in particular, the procedure by which the dispute will be settled in the event that the funded party and the funder do not agree. ${ }^{26}$ In some situations, funders may reserve the right of approval of the settlement. ${ }^{27}$ Settlement may be triggered by different motives of claimants - a claimant may decide to settle without any payment from the opposing party if for instance the respondent presents a business opportunity to the claimant or some other type of future value in exchange for settling the dispute. The funder would certainly have a say in this type of settlement attempt, and it is a question whether the funding agreement would allow this kind of liberty to the funding party.

24 G. Born, op.cit., 2494.

25 Code of Lawyers' Professional Ethics, Official Gazette of the Republic of Serbia, No. 27/2012 and $159 / 2020$.

26 Third Party Funding in International Arbitration, https://www.ashurst.com/en/news-andinsights/legal-updates/quickguide---third-party-funding-in-international-arbitration/, accessed 23 September 2021.

27 Ibidem. 
Hence, a decision-making power is not solely on the client - a certain level of power (which is not to be disregarded) lies also on the funder. The lawyer therefore needs to address both of these decision-making points - both its client and the third-party funder and needs to carefully coordinate and manage the interests of these two. Any important decision in the dispute needs to be run through both the client and the funder, and clear authorities between the client and the funder need to be established and defined in that respect. The lawyer needs to carefully address the requests of the funder when important questions in the dispute arise. Some authors consider that the lawyer ends up being the intermediary bringing funders and litigants together. ${ }^{28}$ The situation becomes particularly complex when for instance the funders agree to take an equity share in the claimant's company. ${ }^{29}$ When this happens, the lawyer may not only find it difficult to prioritize his client's interests but additionally he may struggle to identify who his client is. ${ }^{30}$

Additionally, in order to fund the case, third-party funders often require a familiar law firm to be engaged. It is often the case that the funder requires this to be an international law firm, with which the funder had a previous relationship and cooperation. This to some extent limits the clients in choosing their legal counsel and hence choosing the strategy in the case. It should be noted that this is not a major obstacle in practice as the funders usually leave freedom to clients to retain their local counsel or lawyers of trust, provided an international law firm is part of the team representing the client. This minor factor is however somewhat limiting the client in its freedom to choose its own representation and access justice under its own terms.

With all this, it becomes increasingly difficult to maintain the notion of the interests of the litigant being in the primary focus of both the funders and the lawyers. Precisely for these reasons, Association of Litigation Funders of England and Wales adopted a Code of Conduct in 2011, which set out the basic principles of conduct towards a represented party. In a nutshell, this Code sets guidelines for a funder to: (1) take reasonable steps to ensure that the funded party has received independent advice on the terms of the funding agreement; (2) not take any steps that influence the funded party's lawyers to act in breach of their professional duties, and (3) not seek to influence the funded party's lawyers to cede control or conduct over the

28 Third Party Litigations funds and the lawyer's ethics, https://www.leidenlawblog.nl/articles/ third-party-litigations-funds-and-the-lawyers-ethics, accessed 28 September 2021.

29 Third Party Funding in International Arbitration, https://www.ashurst.com/en/news-andinsights/legal-updates/quickguide---third-party-funding-in-international-arbitration/, accessed 23 September 2021.

30 Third Party Litigations funds and the lawyer's ethics, https://www.leidenlawblog.nl/articles/ third-party-litigations-funds-and-the-lawyers-ethics, accessed 28 September 2021. 
dispute to the funder. These principles are certainly welcome, but the problem is that the Code of Conduct is not a mandatory regulation, and most importantly it is a code for the funder and in no way limits or obliges the lawyers to honor it. Therefore, the need for the rules of conduct and ethical codes for lawyers to address and regulate the issues of third-party funding becomes more and more evident. ${ }^{31}$

\section{ACCESS TO JUSTICE CONSIDERATIONS}

Let us start from some definitions of access to justice:

A person or entity facing a legal issue they could benefit from or be hurt by, should have timely and affordable access to: (a) the appropriate level of legal assistance, and (b) a fair and efficient court or process to resolve disputes, so that they can understand and make decisions about their legal issue; get a fair and costeffective resolution on the facts and applicable law; and feel like they were heard, were treated fairly, and understood the outcome. ${ }^{32}$

Ability to take the case to arbitration or court is just one element of access to justice. This is the element that will be the subject of this analysis. One may say that ability to initiate and conduct the case by the claimant who would, without the funder, not be able to take its case forward, is an obvious contribution to the access to justice.

However, there are some differences which make the entire analysis not so one-sided. Firstly, there is a profit element in third-party funding which is not to be disregarded. The motivation of third-party funder is solely (or in a major part) to make a profit out of the winning case. In this regard, the size and value of the claim influence drastically the funder's decision whether it will fund the case. Funders will require a certain investment to quantum ratio ${ }^{33}$ - some funders do not want to even consider cases which are below EUR 10 million $^{34}$ or sometimes even EUR 20 million. Therefore, we have an entire range of claimants below this threshold which do not have access to justice with third-party funding. Secondly, only certain types of cases are interesting to third-party funders, i.e. damages claims. As mentioned,

31 Third Party Litigations funds and the lawyer's ethics, https://www.leidenlawblog.nl/articles/ third-party-litigations-funds-and-the-lawyers-ethics, accessed 28 September 2021.

32 Bob Glaves, What Do We Mean When We Say Access to Justice?, https://chicagobarfoundation. org/blog/bobservations/what-do-we-mean-when-we-say-access-to-justice/, accessed 20 September 2021.

33 Third Party Funding in International Arbitration, https://www.ashurst.com/en/news-andinsights/legal-updates/quickguide---third-party-funding-in-international-arbitration/, accessed 23 September 2021.

34 Ibidem. 
in the region of western Balkan the funders would rarely be interested in commercial court disputes or commercial arbitrations (mostly due to low value of these cases and unprofitability). In other words, only investment treaty arbitrations above EUR 10 or 20 million would have access to justice by using third-party funding. Not to mention non-monetary claims - apart from philanthropic activities of third-party funders (and some funders have established this practice) - these claims would certainly be of no interest for the third-party funders. Finally, although there were cases in which third-party funder have funded respondent's side, this is very rare in practice and usually limited to funding of respondents' counterclaims. Presumably, the respondents would need to be ready to pay a premium to the funder in case the claim against the respondent is rejected so that the funding of such case would become interesting to the funder.

The notion of access to justice in its true meaning should ideally imply that all parties have equal access to justice, be it the claimants or respondents, be it the winners or losers. The fact that the funder would rarely fund a case which does not have high chances of success has motivated some authors to conclude that funding helps certain winners to become winners, whereas the losers or winners with slightly riskier or controversial claims are simply not given that much opportunity. ${ }^{35}$

Another important consideration when it comes to the impact of third-party funding on access to justice comes down to the necessity of regulation of the practice of third-party funding. It is a view of the authors that without such regulation, the practice of third-party funder may easily cross to the other side of access to justice benefits. For instance, without the obligation of disclosure of third-party funding arrangements the risk of conflict of interest of arbitrators or practitioners will increase. The reason for this can also be found in the fact that there are limited number of third-party funders operating in the market - the circle of funders with which arbitrators and practitioners have not been in touch in one way or another is going to be more and more narrow. Without the obligation to disclose, the other party's interests may be under threat, as their interests may not be well preserved by arbitrators and practitioners acting on the border of conflict of interest. This way, access to justice of a non-funded party may be breached: "With the link between access to justice and third party funding seems to lean more towards the funded party's right, the opposing party's rights to procedural justice can be overlooked and negatively impacted upon".36

35 Victoria Shannon Sahani, "Rethinking the Impact of Third-Party Funding on Access to Civil Justice”, DePaul Law Review, Vol 69, 2020, 613-614.

36 Yu H., op.cit., 20-34. 
Similarly, third-party funders remain inaccessible to winning parties to enforce the adverse costs directly against the funders. Non-regulation of this issue certainly offends the access to justice of the non-funded party when it comes to collection of adverse costs, which may be significantly high in funded arbitration and court proceedings.

Going further down the line, without certain rules and standards that would regulate the operation of third-party funding, the funding arrangements may become looser and give the funders a power to make crucial decisions in the proceedings and meddle with the interests of the funding party in the way that would hurt the access to justice considerations.

One solution to the problem is certainly the regulation of practice of thirdparty funders. This regulation should be comprehensive in the following directions: (i) arbitration rules should regulate third-party funding arrangements and at least provide for the obligation of disclosure; (ii) codes of lawyers' conduct and ethics should introduce rules and standards of lawyers' when representing funded clients, and ideally, (iii) third-party funders should have their own regulation and rules of conduct. Finally, systematic laws in each jurisdiction, such as arbitration acts or civil procedure codes should touch upon the issue of third-party funding, and thereby institutionalize this practice and make it obligatory to follow the rules in both civil litigation and arbitration. Jurisdictions of Singapore and Hong Kong are a very good example of this all-round regulation which strengthens this institute from all sides (funders, practitioners and arbitrators/judges in the proceedings) and provides a legal framework for operation of third-party funding which enhances the benefits of this institute and promotes and positively contributes to access to justice of all parties concerned.

\section{CONCLUSIONS}

Third-party funding is on the rise. Presumably, at present it is rare to find a practitioner in the field of international arbitration that has not come across thirdparty funding. The circle of known players in this field that mutually cooperated in funded cases is narrowing. This raises a growing concern of conflict of interest in funded arbitration and opens the door for many challenges: (i) in operation of arbitrators who become more prone to the conflict of interest as the number of funded cases rise, (ii) in conduct of lawyers who also become more exposed to their own conflict of interests and the difficulty of their position in the triangle between a client and a funder, (iii) in behavior of funders themselves and their influence over the arbitration in respect of their power to make decisions about the fate of the dispute. 
In this complex setting involving different interests of all participants, regulation of third-party funding becomes increasingly essential. Currently, majority of legal systems do not have any legal guidelines or regulation of third-party funding. This opens the door for many challenges with third-party funding such as conflicts of interest, breach of confidentiality and ethical issues ${ }^{37}$. On the other hand, some arbitration rules have instituted the obligation of disclosure of funding arrangements, which is clearly a positive development. Certain jurisdictions such as Singapore and Hong Kong also set a positive example by introducing an all-round regulation of the institute of third-party funding ensuring that all participants play by the rules.

Contribution of third-party funding to access to justice is undoubtable. However, with increased number of funded arbitrations, and without adequate regulation and setting of basic rules and guidelines, third-party funding is at risk of going to its own detriment and against access to justice considerations. The challenges with third-party funding described in this paper are at jeopardy to intensify if the matter remains unregulated. The authors of this article find that regulation of third-party funding is the key to override these challenges and set the third-party funding in the positive direction towards the promotion and empowerment of access to justice.

\section{MILAN LAZIĆ}

Stariji partner, advokat, Advokatska kancelarija

Karanović \& Partners

MILICA SAVIĆ

Partner, advokat, Advokatska kancelarija

Karanović \& Partners

\section{FINANSIRANJE SPOROVA OD STRANE TREĆIH LICA I PRISTUP PRAVDI}

\section{Rezime}

Cilj ovog rada je analiza uticaja finansiranja sporova od strane trećih lica na pravo na pristup sudu i arbitraži i njihov odnos. Polazna tačka ove analize je prepoznavanje uobičajenih problema i izazova u slučaju postojanja trećih lica koja finansiraju određeni spor i imaju sopstveni finansijski interes za uspeh strane koju finansiraju. Autori se kroz rad bave pitanjem da li je ove probleme i izazove moguće prevazići uz postojeću regulativu ovog pitanja. Prepoznat je nedostatak sveobuhvatne i opšte prihvaćene regulative u ovoj oblasti koji povećava rizik postojanja neotkrivenih sukoba interesa

37 H. Yu, op.cit., 20-34. 
između učesnika u sporovima, što utiče na mogućnost očuvanja poverljivosti postupka, efikasnost i pravičnost u postupanju. Iako je nesumnjivo da finansiranje sporova od strane trećih lica doprinosi široj mogućnosti pristupa pravdi, autori su mišljenja da nedovoljno razvijena regulativa u ovoj oblasti može proizvesti i potpuno suprotne efekte na pravo na pristup pravdi. Autori zaključuju da je potrebno uvesti regulativu u ovoj oblasti, kako kroz nacionalna zakonodavstva tako i kroz arbitražna pravila arbitražnih institucija.

Ključne reči: arbitraža, finansiranje sporova od strane trećih lica, sukob interesa, poverljivost, pristup pravdi

\section{Bibliography}

Born G., International Commercial Arbitration, 2nd edition, 2014.

Glaves B., What Do We Mean When We Say Access to Justice?, https://chicagobarfoundation.org/blog/bobservations/what-do-we-mean-when-we-say-access-to-justice/.

Shannon Sahani V., "Rethinking the Impact of Third-Party Funding on Access to Civil Justice”, DePaul Law Review, Vol 69, 2020.

Vijayvergia C., "Balancing Disclosure and Confidentiality Obligations in Third-Party Funding”, Arbitration \& Corporate Law Review, 2020.

Von Goeler J., "Third-Party Funding in International Arbitration and its Impact on Procedure", Kluwer Law International, 2016.

Yu H., “Can Third Party Funding Deliver Justice in International Commercial Arbitration?”, International Arbitration Law Review, 2017.

Article history

Received: 11.10.2021.

Accepted: 27.10.2021.

REVIEW PAPER 